\title{
Peningkatan Keterampilan Komunikasi Lisan Siswa sebagai Fungsi dari Teknik Instruksi Diri
}

\author{
Diah Ayu Pratiwi Ningsih, Edy Legowo, Rian Rokhmad Hidayat \\ Program Studi Bimbingan dan Konseling, Fakultas Keguruan Ilmu Pendidikan, Universitas Sebelas Maret, \\ J1. Ir. Sutami No.36A, Surakarta, Jawa Tengah, Indonesia 57126 \\ E-mail: rianrh@staff.uns.ac.id
}

Artikel diterima: 7 Juni 2017; direvisi 10 September 2017; disetujui 12 September 2017

\begin{abstract}
The purpose of this study was to test the effectiveness of self-instruction techniques to improve student's oral communication skills in the learning process. This study was an experimental study using a single case experimental with A-B designs. The subject was three students from tenth grade senior high school which had a problem with their oral communication during the learning process. Oral communication skills data were collected using Oral Communication Skills Observational Instruments. Data analysis techniques used were statistical analysis with percentage technique, and split-middle technique also clinical analysis technique which declared by significant other. The results show that after carrying out the self-instruction, subject's oral communicating skills in the classroom learning process increases.
\end{abstract}

Keywords: oral communication; self instruction; single subject design

\begin{abstract}
Abstrak: Tujuan penelitian ini adalah menguji keefektifan teknik instruksi diri untuk meningkatkan keterampilan berkomunikasi lisan siswa dalam proses pembelajaran. Penelitian ini merupakan penelitian eksperimental menggunakan single case experimental dengan desain A-B. Subjek penelitian yaitu tiga orang siswa kelas sepuluh yang memiliki keterampilan komunikasi lisan rendah dalam proses pembelajaran. Data penelitian dikumpulkan menggunakan instrumen keterampilan komunikasi lisan. Teknik analisis data yang digunakan adalah analisis statistik dengan teknik persentase, dan split middle technique serta teknik analisis klinis yang dinyatakan oleh significant other. Hasil penelitian menunjukkan bahwa setelah melaksanakan teknik instruksi diri, keterampilan berkomunikasi lisan subjek dalam proses belajar di kelas meningkat.
\end{abstract}

Kata kunci: komunikasi lisan; instruksi diri; single subject design

Seseorang akan selalu berkomunikasi dalam semua aktivitasnya (Hariko, 2017). Begitu pula dengan siswa, yang juga berkomunikasi hampir dalam semua aktivitasnya. Siswa perlu memiliki keterampilan komunikasi lisan dalam proses pembelajaran di kelas untuk mengekspresikan pemikiran atau gagasan mereka secara lisan langsung kepada siswa lain atau gurunya. Komunikasi antara guru dan siswa di dalam kelas merupakan komunikasi interpersonal yang bisa saja terjadi satu arah atau dua arah, bergantung pada respon siswa (Miftah, 2009). Jika siswa bersikap pasif, tanpa ada ekspresi pernyataan atau pertanyaan, maka proses komunikasinya hanya berlangsung satu arah dan implikasinya pembelajaran tersebut tidak efektif. Hal tersebut dapat diartikan bahwa dalam proses pendidikan di sekolah yang berlangsung di dalam kelas proses komunikasi antara guru dengan siswa dinilai tidak efektif apabila siswa hanya mendengarkan pernyataan guru tanpa mengekspresikan pendapatnya dalam bentuk pertanyaan atau diskusi. 
Proses pembelajaran dinilai efektif, minimal jika guru dengan siswa aktif berinteraksi terutama secara lisan langsung saat pelajaran berlangsung di kelas. Crebert dkk.( 2011) menerangkan bahwa keterampilan berkomunikasi lisan yang efektif akan membantu siswa untuk meningkatkan kinerja akademis mereka, meningkatkan pilihan pekerjaan, meningkatkan kompetensi profesional, dan meningkatkan efektivitas pribadi. Berdasarkan pendapat tersebut, jelas bahwa berkomunikasi lisan dalam proses pembelajaran di kelas merupakan suatu keharusan bagi setiap siswa, yaitu sebagai bagian dari keefektifan proses belajar mengajar dan keefektifan pribadi siswa itu sendiri.

Kenyataan di lapangan, tidak semua siswa memiliki keterampilan berkomunikasi lisan dalam proses pembelajaran di kelas. Komunikasi lisan selama proses pembelajaran di sekolah sering menjadi masalah karena ukuran kelas (Nordlund, 2004). Ketika siswa mulai aktif berbicara dalam diskusi kelas yang mengakibatkan suara riuh ruang kelas, ada beberapa siswa lain yang merasa terganggu, dan akan mengingatkan teman-temannya untuk diam. Perilaku salah satu siswa yang mengingatkan teman-temannya ketika mereka aktif berdiskusi merupakan suatu punishment atau hukuman. Jika akibat dari sebuah perilaku adalah hukuman, maka perilaku cenderung melemah. Sehingga siswa yang aktif berbicara dalam diskusi kelas akan mengurangi bahkan menghilangkan perilaku bicara dalam diskusi pembelajaran di kelas.

Studi pendahuluan di sekolah tempat penelitian dilakukan menunjukkan bahwa siswa kelas sepuluh sebanyak $87,26 \%$ enggan bertanya, 58,48\% siswa enggan menjawab, dan 58,48\% siswa enggan menanggapi penjelasan guru ketika proses pembelajaran di kelas berlangsung. Hasil studi pendahuluan tersebut menunjukkan bahwa keterampilan komunikasi lisan siswa kelas sepuluh dalam proses pembelajaran di kelas tergolong masih rendah. Hal lain yang juga mendukung rendahnya komunikasi lisan di kelas yaitu adanya pengalaman negatif siswa saat mengutarakan pendapat dikelas.

Dari hasil wawancara diperoleh data bahwa beberapa siswa sering diabaikan oleh guru, diberi jawaban yang kurang sesuai dengan harapan siswa, pertanyaannya ditertawakan oleh teman lain, dan kurangnya kesempatan yang diberikan guru kepada siswa untuk aktif berkomunikasi lisan dalam proses pembelajaran. Pengalaman-pengalaman tersebut merupakan pemicu yang dapat menyebabkan siswa enggan untuk berkomunikasi lisan pada saat proses pembelajaran di kelas. Upaya yang dilakukan sekolah dalam peningkatan keterampilan berkomunikasi lisan dalam proses pembelajaran sejauh ini bersifat layanan informasi dan belum ada penanganan khusus pada masingmasing siswa yang memiliki keterampilan berkomunikasi lisan rendah. Bantuan yang perlu diberikan pada siswa seyogyanya berfokus pada usaha untuk melatih mereka agar mampu berkomunikasi lisan dengan baik selama proses pembelajaran.

Salah satu teknik yang patut diduga dapat digunakan secara efektif untuk membantu siswa meningkatkan keterampilan berkomunikasi lisannya adalah teknik instruksi diri. Teknik instruksi diri merupakan sebuah teknik yang dilakukan untuk mengarahkan perilaku individu melalui pemberian petunjuk verbal dan berupa perintah kepada dirinya sendiri.

Instruksi diri merupakan prosedur yang dirancang untuk meningkatkan kendali diri secara mandiri melalui pernyataan-pernyataan verbal yang mendorong, membimbing dan memelihara tindakan-tindakan nonverbal (Bryant \& Budd, 1982). Teknik instruksi diri dapat mengendalikan perilaku seseorang melalui penyataan verbal dalam dirinya sendiri. Teknik instruksi diri dapat dilakukan secara mandiri oleh individu dalam mengatasi masalah yang sedang dialaminya. Instruksi diri adalah prosedur yang mudah digunakan untuk mengajar berbagai keterampilan pada berbagai siswa (Goodwin \& Coates, 1976). Instruksi diri yaitu serangkaian prosedur berupa pemberian petunjuk atau pernyataan verbal ke dalam diri seseorang untuk mendorong dan mengarahkan perilakunya agar lebih efektif.

Penerapan instruksi diri dalam menangani masalah keterampilan berkomunikasi lisan dalam proses pembelajaran didasarkan pada psikoedukasi, hal ini dilakukan dengan tujuan bahwa orientasi psikoedukasi lebih ke arah pencegahan masalah serupa di masa depan melalui proses pemberian 
pendidikan secara mental pada masing-masing siswa. Tulisan ini berusaha mengkaji keefektifan teknik instruksi diri untuk meningkatkan keterampilan berkomunikasi lisan dalam proses pembelajaran di kelas.

\section{METODE}

Desain eksperimen kasus tunggal (single case experimental design) dipilih untuk mengetahui keefektifan treatment terhadap suatu fenomena tertentu dengan jumlah subjek yang sedikit atau bersifat individual serta dapat menunjukkan hubungan sebab akibat yang kuat antara variabel bebas dan variabel terikat. Desain A-B digunakan dalam penelitian ini karena tunggal $(\mathrm{N}=1)$ atau satu kelompok kecil subjek yang mendapat perlakuan sama. Desain A-B dikategorikan dalam dua fase, yaitu fase $\mathrm{A}$ atau $\mathrm{A}$, data baseline dikumpulkan sampai menunjukkan data stabil kemudian intervensi diberikan, selanjutnya dilakukan pengumpulan data fase B atau intervensi (Alberto \& Troutman, 2012). Pada desain A-B ini tidak ada pengulangan pengukuran (replikasi), fase baseline (A) dan intervensi (B) dilakukan hanya sekali untuk subjek yang sama. Lebih jelas rencana penelitian digambarkan dalam gambar 1 .

Subjek penelitian ini adalah siswa kelas sepuluh Sekolah Menengah Atas (SMA) Muhammadiyah Karanganyar. Pemilihan subjek penelitian didasarkan pada hasil studi pendahuluan yang kemudian dipilihlah tiga orang subjek penelitian. Karakteristik subjek 1 yaitu merasa kurang percaya diri dalam proses pembelajaran di kelas, malu apabila aktif berkomunikasi lisan dalam proses pembelajaran di kelas, serta takut dimarahi guru apabila aktif bertanya pada saat proses pembelajaran, dan takut diejek teman-temannya apabila terlalu banyak berbicara di kelas seperti bertanya kepada guru tentang materi yang belum jelas. Karakteristik subjek 2 yaitu merasa kurang percaya diri ketika akan aktif berkomunikasi lisan dalam proses pembelajaran di kelas, merasa pesimis akan keterampilannya untuk berkomunikasi lisan dalam proses pembelajaran di kelas, merasa takut akan ditertawakan dan diejek teman-temannya apabila aktif bertanya ketika proses pembelajaran. Karakteristik Subjek 3 yaitu merasa malu apabila akan bertanya kepada guru yang sedang menjelaskan materi pembelajaran, merasa takut apabila aktif berkomunikasi lisan akan diejek teman-temannya, merasa takut pada guru apabila banyak bertanya tentang penjelasan materi pembelajaran, dan kurang percaya diri dalam berkomunikasi lisan ketika berada pada proses pembelajaran di kelas.

Instrumen yang digunakan dalam penelitian ini adalah panduan observasi yang disebut Instrumen Komunikasi Lisan (IKL). IKL dikembangkan dari definisi operasional keterampilan berkomunikasi lisan siswa dalam proses pembelajaran di kelas. Teknik analisis data yang digunakan dalam penelitian ini yaitu analisis split middle technique, teknik persentase, dan teknik analisis klinis dengan metode social validation. Reliabilitas instrumen penelitian IKL didasarkan pada hasil observasi pada fase baseline 1, selanjutnya dihitung menggunakan rumus persentase kesepakatan total (total percent agreement). Dari perhitungan dengan menggunakan rumus persentase kesepakatan total diperoleh hasil $100 \%$, artinya instrumen penelitian IKL dapat dikatakan memiliki tingkat reliabilitas yang sangat baik.

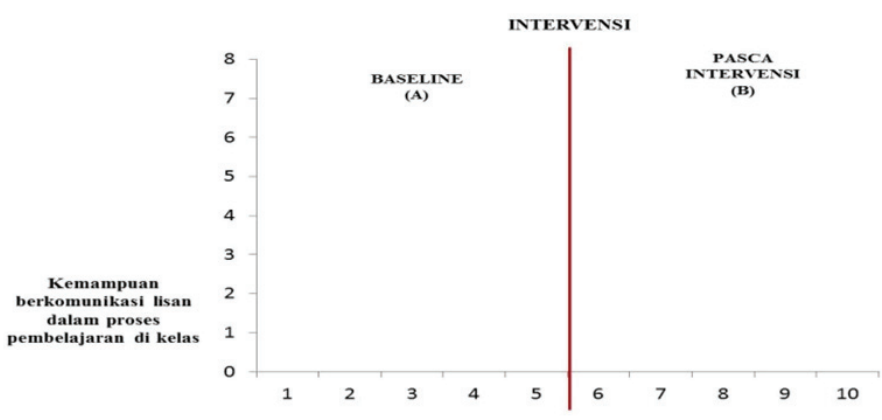

Gambar 1 Rencana Penelitian Desain A-B 


\section{HASIL}

\section{Assessment Fase Baseline}

Assessment data fase baseline dilakukan dengan cara melakukan observasi perilaku berkomunikasi lisan menggunakan instrumen IKL pada proses pembelajaran fisika di kelas subjek. Observasi dilakukan oleh dua orang observer yang mengamati perilaku berkomunikasi lisan subjek dalam proses pembelajaran fisika di kelas dengan alokasi waktu pengamatan 30 menit pada akhir proses pembelajaran. Pengukuran fase baseline dilakukan 5 kali proses pengukuran dengan hasil yang disajikan pada tabel 1 .

\section{Assessment Data Fase Intervensi}

Pada fase intervensi, dilakukan dua kegiatan, yaitu pemberian intervensi pelatihan instruksi diri dan pengumpulan data fase intervensi. Kegiatan intervensi pelatihan instruksi diri untuk aktif berkomunikasi lisan dalam proses pembelajaran di kelas dilakukan dalam empat sesi. Subjek diminta melakukan instruksi diri untuk aktif dalam proses pembelajaran di kelas sesuai urutan teknik instruksi diri sampai subjek merasa terbiasa dan mampu berperilaku sesuai yang diinginkan yaitu mampu berkomunikasi lisan dalam proses pembelajaran di kelas.

Assessment data pada fase intervensi dilakukan dengan cara melakukan observasi perilaku berkomunikasi lisan menggunakan instrumen IKL pada proses pembelajaran. Observasi dilakukan oleh dua orang observer. Masing-masing observer mengamati perilaku berkomunikasi lisan subjek dalam proses pembelajaran fisika di kelas dengan alokasi waktu pengamatan 30 menit pada akhir proses pembelajaran. Pengukuran fase intervensi dilakukan 4 kali proses pengukuran sampai menunjukkan kecenderungan data stabil (komunikasi lisan tinggi) yang ditunjukkan dengan grafik visual. Assessment data fase intervensi dilakukan setelah pemberian intervensi selesai pada tiap sesinya. Assessment data fase intervensi ini bertujuan untuk membandingkan data hasil assessment pada saat baseline dan setelah pemberian intervensi. Data frekuensi keterampilan berkomunikasi lisan pada fase intervensi disajikan pada tabel 2 .

\section{Analisis Uji Hipotesis}

Data kuantitatif didapat berdasarkan hasil assessment data pada fase baseline dan assessment data fase intervensi yang telah dilakukan pada bulan Maret-April 2016. Analisis data kuantitatif yang digunakan dalam penelitian ini yaitu analisis data dengan teknik persentase dan analisis data dengan teknik split-middle technique. Data hasil assessment keterampilan berkomunikasi lisan dalam proses pembelajaran di kelas pada fase baseline dan pada fase pasca intervensi disajikan pada tabel 3.

Berdasarkan data pada tabel 3 dapat dirumuskan mengenai persentase perubahan pada masingmasing subjek penelitian yaitu: (1) perhitungan persentase perubahan perilaku pada subjek 1 berdasarkan analisis persentase tersebut adalah sebesar $(8-4) / 4 \times 100 \%=100 \%$; (2) perhitungan persentase perubahan perilaku pada subjek 2 berdasarkan rumus persentase adalah sebesar $(5,25$ $2,6) / 2,6 \times 100 \%=101,92 \%$; (3) perhitungan persentase perubahan perilaku pada subjek 3 berdasarkan rumus tersebut adalah sebesar $(8,25-4,6) / 4,6 \times 100 \%=96,42 \%$.

Perhitungan persentase pada ketiga subjek menunjukkan hasil 100\% untuk subjek 1, subjek 2 $101,92 \%$, dan subjek $396,42 \%$, artinya perubahan keterampilan berkomunikasi lisan dalam proses pembelajaran yang dialami ketiga subjek penelitian telah mencapai indikator signifikan. Goodwin \& Coates, (1976) menyatakan bahwa perubahan perilaku dapat dikatakan berubah secara signifikan apabila hasil perhitungan dengan rumus tersebut minimal 50\%.

Analisis data menggunakan split middle technique bertujuan untuk mengetahui perubahan level dan perubahan slope pada fase baseline (A) dan fase intervensi (B). Tujuan penggunaan perubahan slope yaitu untuk mengetahui perubahan rata-rata peningkatan skor keterampilan berkomunikasi lisan dalam proses pembelajaran pada masing-masing subjek, sedangkan tujuan penggunaan peru- 
Tabel 1. Frekuensi Keterampilan Berkomunikasi Lisan dalam Proses Pembelajaran Fase Baseline

\begin{tabular}{cccccc}
\hline \multirow{2}{*}{ Subjek } & \multicolumn{5}{c}{ Frekuensi Munculnya Keterampilan Berkomunikasi Lisan dalam } \\
& \multicolumn{5}{c}{ Proses Pembelajaran } \\
\cline { 2 - 6 } & Baseline 1 & Baseline 2 & Baseline 3 & Baseline 4 & Baseline 5 \\
\hline \multirow{2}{*}{1} & $\mathrm{c}, \mathrm{c}, \mathrm{c}, \mathrm{c}$ & $\mathrm{c}, \mathrm{c}, \mathrm{c}, \mathrm{c}$ & $\mathrm{c}, \mathrm{c}, \mathrm{c}, \mathrm{c}, \mathrm{c}$ & $\mathrm{c}, \mathrm{c}, \mathrm{c}$ & $\mathrm{c}, \mathrm{c}, \mathrm{c}, \mathrm{c}$ \\
2 & $\mathrm{c}, \mathrm{c}$ & $\mathrm{c}, \mathrm{c}, \mathrm{c}$ & $\mathrm{c}, \mathrm{c}, \mathrm{c}$ & $\mathrm{c}, \mathrm{c}$ & $\mathrm{c}, \mathrm{c}, \mathrm{c}$ \\
3 & $\mathrm{c}, \mathrm{c}, \mathrm{c}, \mathrm{c}$ & $\mathrm{c}, \mathrm{c}, \mathrm{c}, \mathrm{c}, \mathrm{c}$ & $\mathrm{c}, \mathrm{c}, \mathrm{c}, \mathrm{c}$ & $\mathrm{c}, \mathrm{c}, \mathrm{c}$ & $\mathrm{c}, \mathrm{c}, \mathrm{c}, \mathrm{c}, \mathrm{c}$ \\
\hline
\end{tabular}

Keterangan

a : Bertanya kepada guru saat proses pembelajaran berlangsung

$\mathrm{b}$ : Bertanya kepada guru ketika diberi kesempatan mengajukan pertanyaan

$\mathrm{c}:$ Merespon pertanyaan yang diajukan oleh guru selama proses penjelasan materi pembelajaran

$\mathrm{d}$ : Menanggapi jawaban teman yang tidak sesuai dengan konteks materi pembelajaran berlangsung

e : Menanggapi penjelasan materi guru yang dirasa belum jelas

$\mathrm{f}$ : Memberikan umpan balik pada tanggapan teman dalam diskusi materi pembelajaran

Tabel 2. Frekuensi Keterampilan Berkomunikasi Lisan dalam Proses Pembelajaran Fase Intervensi

\begin{tabular}{|c|c|c|c|c|}
\hline \multirow{2}{*}{ Subjek } & \multicolumn{4}{|c|}{$\begin{array}{c}\text { Frekuensi Munculnya Keterampilan Berkomunikasi Lisan dalam Proses } \\
\text { Pembelajaran }\end{array}$} \\
\hline & Intervensi 1 & Intervensi 2 & Intervensi 3 & Intervensi 4 \\
\hline 1 & $\mathrm{c}, \mathrm{b}, \mathrm{c}, \mathrm{e}, \mathrm{c}, \mathrm{c}, \mathrm{e}, \mathrm{c}$ & $b, e, d, b, e, f$ & $\mathrm{c}, \mathrm{c}, \mathrm{d}, \mathrm{b}, \mathrm{c}, \mathrm{f}, \mathrm{c}, \mathrm{c}, \mathrm{c}$ & $\mathrm{c}, \mathrm{c}, \mathrm{a}, \mathrm{d}, \mathrm{e}, \mathrm{a}, \mathrm{c}, \mathrm{e}$ \\
\hline 2 & $\mathrm{c}, \mathrm{c}, \mathrm{d}, \mathrm{c}, \mathrm{c}$ & $\mathrm{c}, \mathrm{d}, \mathrm{c}, \mathrm{d}, \mathrm{c}, \mathrm{c}$ & $\mathrm{c}, \mathrm{a}, \mathrm{d}, \mathrm{c}, \mathrm{d}$ & $\mathrm{c}, \mathrm{b}, \mathrm{d}, \mathrm{e}, \mathrm{c}, \mathrm{d}, \mathrm{c}$ \\
\hline 3 & $\mathrm{~b}, \mathrm{c}, \mathrm{d}, \mathrm{c}, \mathrm{d}, \mathrm{c}, \mathrm{d}$ & $\mathrm{c}, \mathrm{c}, \mathrm{c}, \mathrm{b}, \mathrm{d}, \mathrm{c}, \mathrm{d}, \mathrm{c}$ & $\mathrm{c}, \mathrm{c}, \mathrm{a}, \mathrm{c}, \mathrm{d}, \mathrm{a}, \mathrm{d}, \mathrm{c}, \mathrm{d}$ & $\mathrm{c}, \mathrm{c}, \mathrm{a}, \mathrm{d}, \mathrm{c}, \mathrm{d}, \mathrm{c}, \mathrm{d}, \mathrm{c}$ \\
\hline
\end{tabular}

Keterangan

a : Bertanya kepada guru saat proses pembelajaran berlangsung

$\mathrm{b}:$ Bertanya kepada guru ketika diberi kesempatan mengajukan pertanyaan

c : Merespon pertanyaan yang diajukan oleh guru selama proses penjelasan materi pembelajaran

$\mathrm{d}$ : Menanggapi jawaban teman yang tidak sesuai dengan konteks materi pembelajaran berlangsung

e : Menanggapi penjelasan materi guru yang dirasa belum jelas

$\mathrm{f}$ : Memberikan umpan balik pada tanggapan teman dalam diskusi materi pembelajaran

Tabel 3 Hasil Assessment Data Baseline dan Fase Intervensi

\begin{tabular}{|c|c|c|c|c|c|c|c|c|c|c|c|}
\hline \multirow{2}{*}{ Subjek } & \multicolumn{5}{|c|}{ Skor Fase Baseline } & \multirow{2}{*}{ Rata-rata } & \multicolumn{4}{|c|}{ Skor Fase Intervensi } & \multirow{2}{*}{ Rata-rata } \\
\hline & 1 & 2 & 3 & 4 & 5 & & 1 & 2 & 3 & 4 & \\
\hline 1 & 4 & 4 & 5 & 3 & 4 & 4 & 8 & 7 & 9 & 8 & 8 \\
\hline 2 & 2 & 3 & 3 & 2 & 3 & 2,6 & 4 & 5 & 5 & 7 & 5,25 \\
\hline 3 & 4 & 5 & 4 & 3 & 5 & 4,2 & 7 & 8 & 9 & 9 & 8,25 \\
\hline
\end{tabular}

bahan level yaitu untuk menunjukkan tingkat perubahan kenaikan poin antara fase baseline dengan intervensi. Analisis data menggunakan split middle technique pada masing-masing subjek disajikan pada tabel 4.

Tabel 4 menunjukkan analisis data menggunakan split middle technique pada masing-masing subjek penelitian. Analisis data split middle technique menunjukkan adanya perubahan slope dengan cara membagi skor slope tinggi dengan skor slope rendah. Perubahan level dihitung dengan cara membagi median tertinggi dengan median terendah dari fase baseline maupun intervensi.

Analisis data dengan split middle technique tidak hanya dilakukan dengan cara perhitungan secara matematis saja, namun juga menggunakan visual inspection untuk melihat kecenderungan arah garis terhadap grafik data pada fase baseline maupun intervensi. Kecenderungan garis pada grafik data fase baseline dapat dipakai untuk memprediksi arah garis pada fase intervensi. 
Tabel 4 Perbandingan Slope dan Level pada Fase Baseline dan Fase Intervensi

\begin{tabular}{ccccccccccc}
\hline Subjek & \multicolumn{3}{c}{ Baseline } & \multicolumn{1}{c}{ Intervensi } & \multicolumn{3}{c}{ Slope } & \multicolumn{3}{c}{ Level } \\
\cline { 2 - 11 } & $\mathbf{X r}$ & $\mathbf{X t}$ & $\mathbf{X r}$ & $\mathbf{X t}$ & $\begin{array}{c}\text { Base- } \\
\text { line }\end{array}$ & $\begin{array}{c}\text { Inter- } \\
\text { vensi }\end{array}$ & $\begin{array}{c}\text { Peru- } \\
\text { bahan }\end{array}$ & $\begin{array}{c}\text { Base- } \\
\text { line }\end{array}$ & $\begin{array}{c}\text { Inter- } \\
\text { vensi }\end{array}$ & $\begin{array}{c}\text { Peru- } \\
\text { bahan }\end{array}$ \\
\hline 1 & 3 & 5 & 7 & 9 & 1,6 & 1,28 & 1,25 & 4 & 7,5 & 1,875 \\
2 & 2 & 3 & 4 & 7 & 1,5 & 1,75 & 1,16 & 2,5 & 5 & 2 \\
3 & 3 & 5 & 7 & 9 & 1,25 & 1,28 & 1,024 & 4,5 & 9 & 2 \\
\hline $\begin{array}{c}\text { Rata- } \\
\text { Rata }\end{array}$ & & & & & & & 1,144 & & & 1,958 \\
\hline
\end{tabular}

Keterangan

$\mathrm{Xr}$ : Skor Terendah

Xt : Skor Tertinggi

Tabel 4 menunjukkan subjek 1 mengalami perubahan slope sebesar 1,25 poin, hal ini dapat diartikan bahwa setiap kenaikan skor keterampilan berkomunikasi lisan dalam proses pembelajaran pada fase intervensi terjadi perubahan kenaikan sebesar 1,25 poin. Perubahan level sebesar 1,875 poin menunjukkan tingkat kenaikan skor keterampilan berkomunikasi lisan dalam proses pembelajaran antara fase baseline dengan fase intervensi. Selanjutnya, data keterampilan komunikasi lisan subjek 1 selama fase baseline dan fase intervensi digambarkan pada gambar 2. Sebagaimana dapat dilihat pada gambar 2, kecenderungan data fase baseline data komunikasi lisan rendah/turun dan pada fase intervensi data komunikasi lisan tinggi/meningkat.

Tabel 4 menunjukkan bahwa selama fase baseline dan fase intervensi subjek 2 mengalami perubahan slope sebesar 1,16, hal ini berarti bahwa setiap kenaikan skor keterampilan berkomunikasi lisan dalam proses pembelajaran pada fase intervensi terjadi perubahan kenaikan sebesar 1,16 poin. Perubahan level sebesar 2 poin menunjukkan tingkat kenaikan skor keterampilan berkomunikasi lisan dalam proses pembelajaran antara fase baseline dan fase inter-vensi. Selanjutnya, data keterampilan komunikasi lisan subjek 2 selama fase baseline dan fase intervensi digambarkan pada gambar 3 . Sebagaimana dapat dilihat pada gambar 3, kecenderungan data fase baseline data komunikasi lisan rendah/turun dan pada fase intervensi data komunikasi lisan tinggi/meningkat.

Tabel 4 menunjukkan bahwa selama fase baseline dan fase intervensi subjek 3 mengalami perubahan slope sebesar 1,024, hal ini berarti bahwa setiap kenaikan skor keterampilan berkomunikasi lisan dalam proses pembelajaran pada fase intervensi terjadi perubahan kenaikan sebesar 1,024 poin. Perubahan level sebesar 2 poin menunjukkan tingkat kenaikan skor keterampilan berkomunikasi lisan dalam proses pembelajaran antara fase baseline dengan fase intervensi. Selanjutnya, data keterampilan komunikasi lisan subjek 3 selama fase base-line dan fase intervensi digambarkan pada gambar 4. Sebagaimana dapat dilihat pada gambar 4, kecenderungan data fase baseline data komunikasi lisan rendah/turun dan pada fase intervensi data komunikasi lisan tinggi/meningkat.

\section{Analisis Klinis}

Analisis klinis yang dilakukan berdasarkan pada hasil wawancara pada ketiga teman sebangku masing-masing subjek. Wawancara hanya dilakukan dengan teman sebangku masing-masing subjek karena mereka dirasa sangat mengenal karakteristik masing-masing subjek secara khusus. Teman sebangku subjek yang dimaksud adalah: (1) Dr, teman sebangku subjek 1; (2) Agt, teman sebangku subjek 2; dan (3) Pln, teman sebangku subjek 3. Menurut Dr, subjek 1 sekarang cenderung banyak berubah dibandingkan sebelumnya, subjek 1 sekarang lebih baik daripada sebelumnya, subjek 1 menjadi lebih berani bertanya kepada guru dan lebih rajin, sudah tidak terlalu bergantung pada Dr dan subjek 1 lebih berani mengutarakan pendapatnya sendiri.

Menurut Agt, subjek 2 sekarang lebih berani dibandingkan sebelumnya, subjek 2 lebih cepat dan tanggap merespon guru maupun teman-temannya pada saat proses pembelajaran berlangsung, subjek 2 sekarang lebih berani berbicara atau aktif di kelas. Selanjutnya, menurut Agt subjek 2 


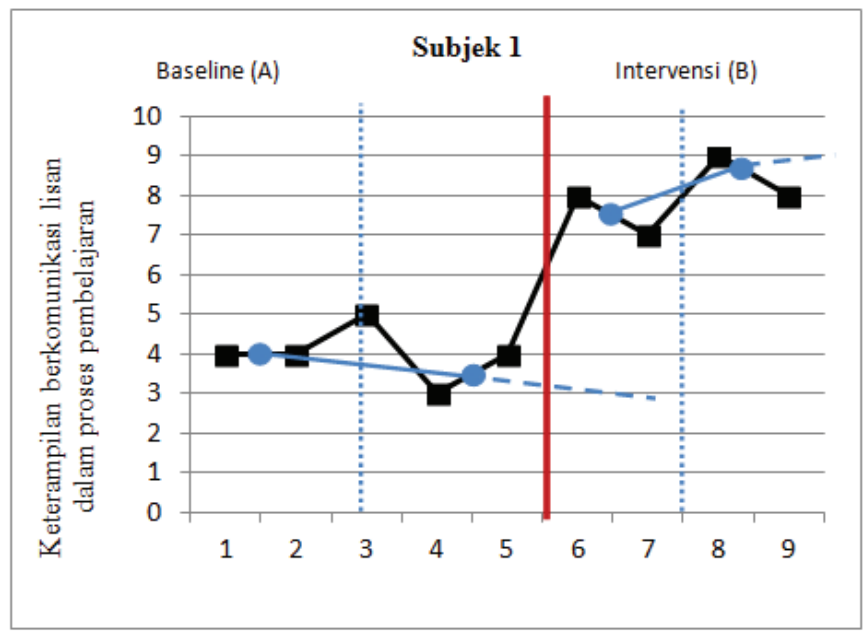

Gambar 2 Grafik Visual Inspection Subjek 1

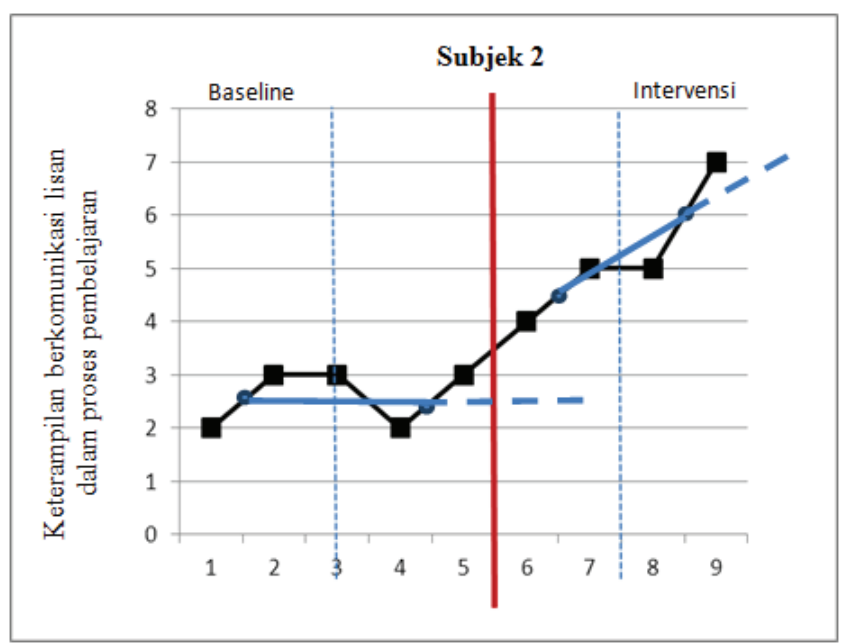

Gambar 3 Grafik Visual Inspection Subjek 2

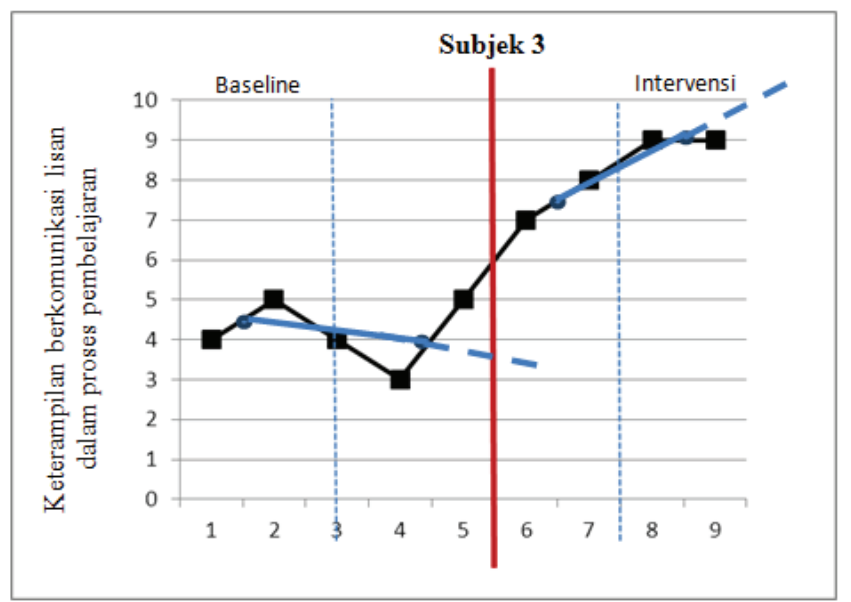

Gambar 4 Grafik Visual Inspection Subjek 3 
sekarang ada sedikit perubahan dalam setiap pelajaran di kelas, subjek 2 lebih memerhatikan guru yang sedang menerangkan pelajaran dibandingkan sebelumnya, subjek 2 sekarang lebih cenderung berani bertanya kepada teman-teman yang lain dan sesekali berani mengajukan pertanyaan kepada guru yang sedang mengajar.

Menurut Pln, subjek 3 sekarang nampak berubah, subjek 3 lebih berani bergaul dengan temanteman yang lain, subjek 3 kadang-kadang berani bertanya kepada guru yang sedang menerangkan pelajaran di kelas, perubahan pada subjek 3 menurut Pln lebih baik dibandingkan dulu sewaktu masih awal mengenal subjek.

Data hasil wawancara dengan ketiga teman sebangku masing-masing subjek tersebut kemudian dibandingkan dengan data assessment pada fase baseline yang dilakukan oleh observer. Berdasarkan data keterampilan berkomunikasi lisan dalam proses pembelajaran pada fase baseline dan fase intervensi, terdapat kenaikan intensitas keterampilan berkomunikasi lisan dalam proses pembelajaran dari fase baseline menuju fase intervensi. Perubahan intensitas keterampilan berkomunikasi lisan subjek penelitian benar-benar karena pengaruh intervensi, karena sebelumnya diukur terlebih dahulu pengetahuan subjek mengenai teknik instruksi diri.

Subjek 1 mengalami kenaikan keterampilan berkomunikasi lisan dalam proses pembelajaran sebesar 23 poin diikuti kenaikan keterampilan instruksi diri sebesar 50 poin. Hal ini berarti kenaikan pengetahuan subjek 1 mengenai teknik instruksi diri sebesar 50 poin dapat meningkatkan keterampilan berkomunikasi lisan subjek 1 dalam proses pembelajaran fisika di kelas sebesar 23 poin.

Subjek 2 mengalami kenaikan keterampilan berkomunikasi lisan dalam proses pembelajaran sebesar 23,5 poin diikuti kenaikan keterampilan instruksi diri sebesar 50 poin. Hal ini berarti kenaikan pengetahuan subjek 2 mengenai teknik instruksi diri sebesar 50 poin dapat meningkatkan keterampilan berkomunikasi lisan subjek 2 dalam proses pembelajaran fisika di kelas sebesar 23,5 poin.

Subjek 3 mengalami kenaikan keterampilan berkomunikasi lisan dalam proses pembelajaran sebesar 25 poin diikuti kenaikan keterampilan instruksi diri sebesar 50 poin. Hal ini berarti kenaikan pengetahuan subjek 3 mengenai teknik instruksi diri sebesar 50 poin dapat meningkatkan keterampilan berkomunikasi lisan subjek 3 dalam proses pembelajaran fisika di kelas sebesar 25 poin.

Berdasarkan pemaparan hasil dari ketiga subjek diketahui bahwa keterampilan berkomunikasi lisan dalam proses pembelajaran masing-masing subjek mengalami peningkatan setelah pemberian intervensi. Hasil analisis persentase dan analisis klinis juga menunjukkan bahwa keterampilan berkomunikasi lisan subjek dalam proses pembelajaran di kelas meningkat.

\section{PEMBAHASAN}

Keterampilan berkomunikasi lisan dipengaruhi banyak faktor. Faktor-faktor tersebut dapat dikategorikan dalam dua kelompok, yakni faktor yang menghambat dan faktor yang mendukung. Faktor yang menghambat keterampilan berkomunikasi lisan dalam proses pembelajaran yakni anteseden berupa lingkungan kelas yang kurang mendukung keaktifan siswa sebagai bentuk keterampilan berkomunikasi lisan dalam proses pembelajaran di kelas seperti guru yang tidak memberikan kesempatan untuk aktif dan kurang menghargai keterampilan siswa serta teman-teman kelas cenderung mengejek temannya yang aktif pada saat proses pembelajaran.

Faktor yang mendukung tingginya komunikasi lisan siswa di kelas antara lain sikap respek guru terhadap siswa dan lingkungan kelas yang mendukung (Goss, Sonnemann, \& Griffiths, 2017). Selain itu harapan guru terhadap siswa juga memengaruhi keaktifan siswa di kelas (Papageorge \& Gershenson, 2016).

Berbagai anteseden dan prior learning yang telah di sebutkan sebelumnya menjadikan siswa memunculkan berbagai respon. Anteseden dan prior learning merupakan sesuatu yang memengaruhi pembentukan perilaku seorang individu berdasarkan social learning theory. Nama lain dari social 
learning yaitu cognitive behavior (Bandura dalam Hitipeuw, 2009), cognitive behavior merupakan dasar dari teori cognitive behavior therapy yang salah satu diantaranya adalah instruksi diri. Hal ini berarti ada hubungan kuat dari teknik instruksi diri dan keterampilan berkomunikasi lisan dalam proses pembelajaran di kelas.

Prosedur teknik instruksi diri yang diterapkan mengacu pada social learning theory. yakni tidak hanya cognitive modelling saja, tetapi juga imitasi dan modelling. Berdasarkan social learning theory, perilaku yang diinginkan akan terbentuk karena adanya anteseden berupa cues visual maupun auditory, model perilaku, serta prior learning dan perilaku tersebut akan diteruskan apabila mendapat reinforcement, sebaliknya perilaku tersebut akan berkurang atau bahkan dihentikan ketika mendapat punishment (Goodwin \& Coates, 1976). Melalui prosedur teknik instruksi diri yang menekankan pada unsur imitasi, modelling dan cognitive modelling diharapkan individu akan memperoleh kendali akan perilakunya sendiri.

Instruksi diri yang dilakukan oleh siswa mampu meningkatkan usaha dan ketekunan siswa (Christenson, Reschly, \& Wylie, 2012). Intruksi diri juga terbukti dapat digunakan untuk meningkatkan kepercayaan diri siswa (Fiorentika, Santoso, \& Simon, 2016). Bahkan efikasi diri sosial siswa pun dapat ditingkatkan dengan teknik instruksi diri (Dewi, Atmoko, \& Triyono, 2016). Pada saat intervensi diberikan kepada subjek, mereka mendapatkan gambaran mengenai perilaku yang seharusnya dalam proses pembelajaran di kelas. perilaku yang dimaksud yakni mampu berkomunikasi lisan dalam proses pembelajaran di kelas melalui proses imitasi dan modelling dari teman-teman di kelas. Selain itu, instruksi yang mereka berikan kepada diri mereka seperti "Saya pasti bisa menjawab pertanyaan guru", "Saya berani bertanya agar mendapat jawaban yang benar", dan "Saya mampu menyampaikan pendapat saat berdiskusi" mampu memaksa dan membentuk perilaku berkomunikasi lisan dalam proses pembelajaran di kelas secara efektif. Instruksi diri dapat membuat siswa untuk fokus pada tugas dan mengoptimalkan usaha dalam menyelesaikan permasalahan-permasalahan akademik di kelas (Davidson \& Sternberg, 2003).

Lestari, (2009) menyatakan bahwa ada korelasi positif antara imitasi perilaku belajar dengan motivasi belajar pada siswa sekolah menengah pertama. Hal ini dapat memperkuat pernyataan bahwa proses imitasi dapat mendorong atau memotivasi seseorang untuk membentuk perilaku baru. Individu yang mengimitasi perilaku belajar orang disekitarnya, lama kelamaan akan memunculkan perilaku tersebut. Proses peniruan perilaku orang-orang sekitar individu memberikan gambaran mengenai perilaku yang seharusnya dilakukan individu tersebut dalam lingkungannya.

Anak mendapatkan motivasi untuk memperbaiki kepribadiannya dengan menjadikan model yang mendapatkan reward sebagai contoh gambaran untuk membentuk kepribadian (Bandura, 1963). Proses imitasi dari model yang mendapatkan reward menjadikan anak termotivasi membentuk kepribadian. Berdasarkan hasil penelitian tersebut jelas bahwa imitasi dapat memberi peran penting dalam pembentukan kepribadian anak.

Model perilaku sangat berpengaruh dalam perubahan perilaku anak (Schunk,1987). Terutama jika model perilaku tersebut adalah sebaya yang sehari-hari bersama anak tersebut. Dapat disimpulkan bahwa orang-orang disekitar anak yang dijumpai setiap hari mampu memberikan pengaruh yang kuat terhadap perubahan perilaku anak tersebut. Hal tersebut sejalan dengan hasil penelitian Putra, Suarni, \& Putri, (2014) yang menyebutkan bahwa konseling behavioral dengan teknik modelling efektif untuk mengoptimalkan penyesuaian diri siswa. Siswa memperoleh gambaran mengenai cara penyesuaian diri yang seharusnya melalui proses peragaan model kemudian siswa tersebut mempraktekkannya sendiri. Siswa yang diajari untuk membentuk perilaku atau penyesuaian diri dalam lingkungan pembelajaran di sekolah, lama-kelamaan akan terbiasa dan terkondisikan. Sehingga siswa tersebut dapat menunjukkan perilaku yang sesuai harapan yaitu mampu menyesuaikan dirinya dalam lingkungannya.

Selanjutnya, untuk mengajari individu memperoleh gambaran mengenai perilaku yang sesuai harapan, yaitu dengan cognitive modelling, setelah siswa memperoleh gambaran mengenai perilaku yang diharapkan dan telah diperagakan oleh model perilaku, diusahakan model perilaku yang mencontohnya yaitu model yang berkompeten. Model perilaku tersebut adalah model yang 
benar-benar mampu berkomunikasi lisan dalam proses pembelajaran di kelas. Pemilihan model yang berkompeten, dapat menentukan bentuk perilaku yang seharusnya dilakukan atau dicontoh kemudian diperagakan oleh subjek penelitian atau siswa. Ketika memperoleh gambaran mengenai arah dan bentuk perilaku komunikasi lisan dalam proses pembelajaran yang diharapkan, siswa hendaknya mampu melakukan instruksi diri, untuk lebih kuat dalam mengarahkan atau membentuk perilaku mampu berkomunikasi lisan dalam proses pembelajaran di kelas.

Instruksi diri merupakan salah satu teknik dari cognitive behavior therapy yang memiliki prosedur pemberian petunjuk verbal ke dalam diri seseorang untuk mendorong dan mengarahkan perilakunya agar lebih efektif. Proses pemberian petunjuk verbal pada diri sendiri ini merupakan kunci dari pengarahan sebuah perilaku, individu akan melakukan observasi terhadap perilaku orang lain terlebih dahulu melalui proses imitasi dan modelling, selanjutnya ia akan memproses pemikirannya tentang pelaksanaan perilaku tersebut. Ketika anteseden diperoleh dari model perilaku, maka individu akan memberikan pengarahan pada dirinya tentang perilaku yang seharusnya dilakukan. Pada tahap tersebut penting sekali dilaksanakan instruksi diri, agar perilaku lebih terarahkan secara efektif. Hal ini didukung oleh hasil penelitian Haddadian, Majidi, \& Maleki, (2012) bahwa teknik instruksi diri efektif untuk meningkatkan keterampilan membaca dan mereduksi kecemasan pada siswa dengan gangguan disleksia. Instruksi diri dapat mereduksi masalah-masalah pembelajaran seperti kecemasan, frustasi, depresi dan penghargaan diri yang rendah (low self-esteem) pada siswa yang mengalami gangguan disleksia dan mengatasi perilaku yang tidak peka, sehingga dapat mempersiapkan siswa tersebut untuk mencapai pendidikan yang berhasil.

\section{SIMPULAN}

Berdasarkan hasil analisis data kuantitatif dan hasil analisis klinis dapat disimpulkan bahwa teknik instruksi diri efektif untuk meningkatkan kemampuan berkomunikasi lisan siswa dalam proses pembelajaran di kelas. Subjek mampu mereduksi kecemasan yang dialami lewat intruksi diri sehingga tidak merasa cemas lagi dan mampu berkomunikasi lisan dalam proses pembelajaran di kelas. Hal tersebut dibuktikan dengan peningkatan skor keterampilan berkomunikasi lisan dalam proses pembelajaran di kelas pada ketiga subjek dan diperkuat oleh hasil analisis klinis yang dinyatakan oleh significant other.

Beberapa saran dari tulisan ini diantaranya: (1) guru bidang studi dan guru bimbingan dan konseling diharapkan dapat mengembangkan prosedur pelaksanaan teknik instruksi diri untuk meningkatkan keterampilan berkomunikasi lisan siswa dalam proses pembelajaran dan keterampilan yang lain; (2) guru sebaiknya menerapkan model pembelajaran yang sesuai dengan karakteristik masing-masing siswa dan memberikan reward pada berbagai macam kemampuan yang dimiliki masing-masing siswa; (3) peneliti selanjutnya hendaknya menerapkan hasil penelitian ini pada subjek yang lebih luas dan memberikan kontrol lebih ketat terhadap efek perlakuan pada masingmasing subjek.

\section{DAFTAR RUJUKAN}

Alberto, P. A., \& Troutman, A. C. (2012). Applied Behavior Analysis for Teachers. Pearson Higher Ed.

Bandura, A. (1963). The Role of Imitation in Personality Development. Dimensions of Psychology, $16,121-153$.

Bryant, L. E., \& Budd, K. S. (1982). Self-instructional Training to Increase Independent Work Performance in Preschoolers. Journal of Applied Behavior Analysis, 15(2), 259-271.

Christenson, S. L., Reschly, A. L., \& Wylie, C. (2012). Handbook of Research on Student Engagement. Springer Science \& Business Media.

Crebert, G., Patrick, C. J., Cragnolini, V., Smith, C., Worsfold, K., \& Webb, F. (2011). Teamwork Skills Toolkit. Diambil Juni, 20, 2013. 
Davidson, J. E., \& Sternberg, R. J. (2003). The Psychology of Problem Solving. Cambridge University Press.

Dewi, F. A., Atmoko, A., \& Triyono, T. (2016). Keefektifan Teknik Self Instruction dalam Konseling Cognitive Behavior Counseling untuk Meningkatkan Efikasi Diri Sosial Siswa SMKN 2 Malang. Jurnal Kajian Bimbingan dan Konseling, 1(4), 172-178. http://dx.doi.org/10.17977/ um001v1i42016p172

Fiorentika, K. F., Santoso, D. B., \& Simon, I. M. (2016). Keefektifan Teknik Self-Instruction untuk Meningkatkan Kepercayaan Diri Siswa SMP. Jurnal Kajian Bimbingan dan Konseling, 1(3), 104-111. http://dx.doi.org/10.17977/um001v1i32016p104

Goodwin, D. L., \& Coates, T. J. (1976). Helping Students Help Themselves. Prentice-Hall.

Goss, P., Sonnemann, J., \& Griffiths, K. (2017). Engaging Students: Creating Classrooms that Improve Learning. Victoria: Grattan Institute.

Haddadian, F., Majidi, A., \& Maleki, H. (2012). The Effectiveness of Self-instruction Technique on Improvement of Reading Performance and Reduction of Anxiety in Primary School Students with Dyslexia. Procedia-Social and Behavioral Sciences, 46, 5366-5370.

Hariko, R. (2017). Landasan Filosofis Keterampilan Komunikasi Konseling. Jurnal Kajian Bimbingan dan Konseling, 2(2), 41-49. http://dx.doi.org/10.17977/um001v2i22017p041

Hitipeuw, I. (2009). Belajar \& Pembelajaran. Universitas Negeri Malang.

Lestari, D. S. H. (2009). Hubungan antara Imitasi Perilaku Belajar dengan Motivasi Belajar pada Siswi SMP Vidatra Bontang. (Skripsi tidak diterbitkan) Universitas Ahmad Dahlan, Yogyakarta, Indonesia.

Miftah, M. (2009). Komunikasi Efektif dalam Pembelajaran. Semarang: Pustekkom-Depdiknas.

Nordlund, E. (2004). Oral Communication in English Classes at Senior High School.

Papageorge, N., \& Gershenson, S. (2016). Do Teacher Expectations Matter? Diambil dari https:// www.brookings.edu/blog/brown-center-chalkboard/2016/09/16/do-teacher-expectationsmatter/

Putra, G. A. D., Suarni, N. K., \& Putri, D. A. W. M. (2014). Efektivitas Konseling Behavioral dengan Teknik Modeling untuk Mengoptimalkan Penyesuaian Diri Siswa Kelas X SMK Negeri 2 Singaraja Tahun Pelajaran 2013/2014. Jurnal Ilmiah Bimbingan Konseling, 2(1).

Schunk, D. H. (1987). Peer Models and Children's Behavioral Change. Review of Educational Research, 57(2), 149-174. 